\title{
Consumer Socialization Agents for Young Children: An Exploratory Study
}

\section{Ernest North and Brenda Poggio}

Department of Marketing and Communication Management, University of Pretoria

\section{ABSTRACT}

Although marketers in South Africa are beginning to realise that the youth market is a segment that cannot be ignored, only a limited number of studies have thus far been conducted to examine the consumer behaviour of children. The relevance of this topic to South African marketers suggests the need for research in this field. The purpose of this article is to report the findings of an exploratory study conducted to determine the role or influence of consumer socialization agents in the buying behaviour of primary school children, 9-11 years of age. A broad overview of the nature and processes of consumer socialization is provided, as well as of research conducted in this field over the past few decades. Some important marketing implications are also suggested.

JEL 329

Much consumer behaviour is performed under the influence of others. The very foundation of human behaviour is learning from others.

James McNeal, 1973.

\section{INTRODUCTION}

Scholarly research examining the consumer behaviour of children dates back to the 1950s. Although much has been said and written about the development of children as consumers, not all of this material is based on solid research. The lack of systematic research that examines factors such as children's preferences, spending patterns and how they influence family decision-making, can be ascribed to the fact that marketers may think that it is inappropiate to regard children as a "market" (McNeal in Stipp, 1988); or that people do not consider children to be important enough to warrant expensive research. Children are difficult to study, and empirical findings on those in the elementary school phase, 6-12 years of age, in particular are scarce. They are unreliable reporters 
of their behaviour and feelings, find it difficult to understand abstract questions and have poor recall (Stipp, 1988). McGee (1997: 53) is of the opinion that research with children is "... an even newer idea than selling things to them." Today's children live in a rapidly changing technological world, and have different perspectives on things. A different approach and new kinds of qualitative research must therefore be employed to understand the consumer behaviour of children, and to ascertain the reasons why they feel and act the way they do.

In the South African context, a limited number of studies have thus far investigated the consumer behaviour of children. These studies include focus groups with children to determine, inter alia, the influence- of advertising on their consumer socialization (North, 1987) and their understanding of television advertisements and the influence thereof on their buying decisions (CardwellGardner \& Bennett, 1999). The advancement of a better life and future for children in South Africa is a matter of great concern for the present government. The question arises whether marketers are taking cognisance of this change in the social environment, and whether it is reflected in their marketing strategies.

The dramatic changes that have recently taken place in South Africa have generated many new marketing opportunities. The redistribution of income and rapid westemization of black South Africans is of special interest to South African marketers. They, like their counterparts in other countries, are beginning to realise that the youth market is a segment that cannot be ignored. Furthermore, the changing social climate also reveals the relationship between advertising strategy and the environment. Marketers in South Africa are being challenged to adapt their marketing and advertising strategies to fit in with the new environment created by post-apartheid changes. The limited number of studies of the consumer behaviour of children and the relevance of this topic to South African marketers suggest the need for further research.

The purpose of this article is to report the findings of an exploratory study conducted to investigate the role or influence of consumer socialization agents in the buying behaviour of primary school children, 9-11 years of age. A broad overview will be provided of the nature and processes of consumer socialization and the research conducted in this field during the past few decades. A number of important marketing implications will also be discussed. 


\section{BACKGROUND AND HISTORICAL OVERVIEW}

\section{Consumer Socialization}

Children move through various cognitive and social phases on their journey from birth to adolescence and adulthood. Consumer socialization (which is only a part of a child's general socialization) is described as "the processes by which young people acquire skills, knowledge, and attitudes relevant to their functioning as consumers in the marketplace" (Ward, 1974: 2). Although McNeal (1993) sometimes refers to it as "consumer education" or "consumer development", Ward's description of the concept can be regarded as a universally accepted definition (John, 1999; Carlson \& Grossbart, 1994). John (1999) views consumer socialization as a process that occurs in the context of social and cognitive development as children move through three stages of consumer socialization, namely the perceptual stage (3-7 years), the analytical stage ( $7-11$ years), and the reflective stage ( $11-16$ years).

Children partcipate in many activities during the process whereby they acquire basic consumer skills. According to McNeal (1993), children pass through the following five-stage leaming process in their consumer development:

Stage 1: Observing. This first stage is the child's initial interaction with the marketplace. Mothers usually take their infants to shopping malls and stores where they make sensory contact with the shopping environment. McNeal's (1993) studies show that the median age here was two months, but answers ranged from one to 33 months.

Stage 2: Making requests. During this phase, children make requests (by pointing, gesturing and even making statements) to parents that they see something they want. These requests are made mainly when they are in the presence of store objects. In the latter part of this phase they make requests for objects at home, probably because of the stimulation by television advertisements.

Stage 3: Making selections. When children start walking (3-4 years of age), they experience their first physical contact as consumers by choosing an article and taking it from the shelf. They sometimes wander through the store by themselves. Factors such as the layout of the store, displays and even packaging are becoming important at this stage.

Stage 4: Assisted purchases. Almost from birth, children regularly witness their parents and other shoppers giving money in exchange for goods. These scenes give meaning to the money children receive from their parents or grandparents. This contributes to the child's understanding that the store owns the goods and money is the medium of exchange. 
Stage 5: Making independent purchases. The fifth and final step in the development of consumer behaviour is performing independent purchases without parental assistance. There is usually a significant time lag between a child's first purchase with parents and an independent purchase without them (McNeal \& Yeh, 1993). It is not until the age of eight that children begin to make purchases on their own.

According to Sheth, Mittal and Newman (1999:587), consumer socialization occurs when one or more of the following are learned or acquired by children: "... preferences among altemative brands and products; knowledge about product features and the functioning of the marketplace; and skills in making 'smart decisions' ...". The theory and published literature focus largely on the consumer socialization of children. Engel, Blackwell and Miniard (1995), however, state that it should be recognized as a lifelong process.

\section{Consumer Socialization Agents}

The learning of consumer behaviour patterns (consumer socialization) by children has been of interest to researchers since the end of World War 2. Prevey (in McNeal, Herndon \& Yeh, 1993) reported that children who receive financial training from their parents are better able to use financial resources later in life. In the 1950 s and 1960s, other pioneers such as Guest, McNeal, Berey and Pollay (in John, 1999) started to examine factors related to the consumer behaviour of children. The topics investigated include children's understanding of marketing and retail functions, brand loyalty and the influence of children in family decision-making. Specific studies on the influence of consumer socialization agents in children's buying behaviour were apparently missing in these early years of research. According to Moschis (1987), socialization agents are the persons and organizations involved in the orientation and education as consumers such as family members, peers, mass media, schools and retailers.

The stage was thus set for more widespread research on children, specifically the consumer socialization process of children. John (1999) states that research in this field blossomed and gained momentum in the mid-1970s. Scott Ward's (1974) article entitled "Consumer socialization" which was published in the Joumal of Consumer Research, forcefully argued for studying children and their socialization into the consumer role. This gave focus to a new generation of researchers and an emerging field of research in the field of consumer socialization and the role of socialization agents in children's development as consumers. Ward's work opened up a stream of research in this field, including topics such as children's knowledge of products, advertising, pricing, and decision-making strategies. Of particular importance to this review are the 
studies that focused on children's knowledge about and influence of the family and retail shopping experiences (as socialization agents) on children's development as consumers. Excluded here are research by economists and psychologists pertaining to children's knowledge of money values and their consumption of products such as cigarettes and alcohol (John, 1999).

The family can be regarded as the primary source (agent) of consumer socialization. Hawkins, Best and Coney (1998: 203) state that parents teach their children consumer skills both deliberately and casually through instrumental training, modelling and mediation. Instrumental training occurs, for example, when a parent tries to teach a child to eat a certain snack because it has nutritional value. Modelling occurs when a child learns appropriate (or inappropriate) consumption behaviours by observing others (for example parents who smoke). Mediation occurs when a parent alters a child's initial interpretation of or response to a marketing stimulus (for example an advertisement depicting a situation in which a child will be rewarded with a snack for good behaviour).

A study by McNeal (1993) revealed that children's consumer socialization is greatly enhanced by retailers who act as socialization agents. They learn many consumer skills while visiting shops, supermarkets and shopping malls. The supermarket is normally the first shop children visit. In many cases this is also where they make their first purchase requests and self-selection of a product. Children soon perceive a shop as "child-friendly" and these shops help to form impressions that guide them in their future shopping behaviour.

Table. 1 lists examples of studies conducted in the past three decades on the family and retailers as consumer socialization agents (John, 1999).

Cross-cultural marketing research has recently grown in popularity. It is interesting to note that this kind of research also features in studies on the consumer socialization of children. Recent studies by McNeal, Hemdon and Yeh (1993), McNeal and Ji (1999), and Lee and Marshall (1998) are worth noting. Findings of the McNeal studies indicate that Hong Kong children's patterns of consumer behaviour are becoming increasingly similar to those of US children. Chinese children utilise their parents and retail outlets as important agents for socialization, especially to gain information in order to learn more about new products. McNeal and Ji (1999) report that Chinese children from the age of nine upwards make two or more shopping visits to two or more stores a week, and consequently develop store preferences. The Lee and Marshall study found that New Zealand children exert more influence on family decisionmaking than Singaporean children. New Zealand families are also more democratic in their decision-making than Singaporean families. 


\section{Table 1 Studies on socialization agents 1970-1993}

\begin{tabular}{|c|c|c|}
\hline Author(s) & Topic & Year \\
\hline Atkin, C.K. & $\begin{array}{l}\text { Observation of parent-child interaction } \\
\text { in supermarket decision-making. }\end{array}$ & 1978 \\
\hline $\begin{array}{l}\text { Belch, G., Belch, M. } \\
\text { \& Ceresino, G. }\end{array}$ & $\begin{array}{l}\text { Parental and teenage influences in } \\
\text { family decision-making. }\end{array}$ & 1985 \\
\hline Bums, A. \& Gillett, P. & $\begin{array}{l}\text { Antecedents and outcomes of the family } \\
\text { purchase socialization process for a } \\
\text { child's toys and games. }\end{array}$ & 1987 \\
\hline Carlson, L. \& Grossbart, S. & $\begin{array}{l}\text { Parental style and consumer } \\
\text { socialization of children. }\end{array}$ & 1988 \\
\hline $\begin{array}{l}\text { Haynes, J., Burls, D., } \\
\text { Duke, A. \& Cloud, R. }\end{array}$ & $\begin{array}{l}\text { Consumer socialization of pre-schoolers } \\
\text { and kindergarteners as related to } \\
\text { clothing consumption. }\end{array}$ & 1993 \\
\hline Hempel, J. & $\begin{array}{l}\text { Family buying decisions: A cross- } \\
\text { cultural perspective. }\end{array}$ & 1974 \\
\hline $\begin{array}{l}\text { Isler, L., Popper, E. \& } \\
\text { Ward, S. }\end{array}$ & $\begin{array}{l}\text { Children's purchase requests and } \\
\text { parental responses. }\end{array}$ & 1987 \\
\hline McNeal, J. & Children's perceptions of retail stores. & 1981 \\
\hline Moschis, G. \& Moore, L. & $\begin{array}{l}\text { Family communication and consumer } \\
\text { socialization. }\end{array}$ & 1979 \\
\hline Popper, E. & $\begin{array}{l}\text { Mother's mediation of children's } \\
\text { purchase requests. }\end{array}$ & 1979 \\
\hline
\end{tabular}

The literature study revealed that very little research has been done on the role of the school as a socialization agent. However, one South African study focused on the school's role in educating young children as consumers (North, 1998). The aim of this curriculum development project was to introduce a new subject into the school curriculum. A draft core syllabus for this "new subject" (Economic Education) was compiled, and some of the objectives explicitly stated that pupils need to gain knowledge and skills in order to become skilful consumers. They also need to manage their own money matters responsibly.

\section{METHOD}

\section{Sampling}

In order to gather information on the role of the family and retail shopping experiences as consumer socialization agents for children in the foundation school phase, three focus group interviews were conducted with 18 children (six 
per group). A list of all primary schools in the Pretoria region served as the basis for the sampling procedure. A non-probability convenience sample resulted in the selection of a primary school in the eastern suburbs of Pretoria. The specific school was selected because it represented a balanced blend of language, gender and ethnic diversity.

The teachers were asked to select children between the ages of nine and ten. The children in the sample were old enough to form particular opinions about family decision-making, and children of that age have the potential to provide data because they are still shopping with their mothers (McNeal, 1993: 34). The focus groups were conducted at school because it was the easiest way to reach the children, and they were also in a familiar environment.

Personal interviews were also conducted with ten mothers of children in the above-mentioned age group. The researcher made sure that this convenience sample did not include mothers of the 18 children who constituted the focus groups. The reason for this decision was that a degree of bias may be present if only the mothers of some of the children who were interviewed, were also interviewed. The reason for including mothers in the study is that children spend a lot of time in shops with their mothers who play a primary role in the consumer socialization of their children.

\section{Data Collection}

The researcher and an experienced moderator conducted the focus group interviews with the children in an isolated classroom. A discussion list or interview guide containing relevant topics guided the interviews. Great care was taken in compiling the list to ensure that the research questions or objectives were met. The interview guide contained the following topics that supplied the basis from which questions were asked:

- introduction of the topic (family decision-making and shopping)

- general questions on advertising, money and shopping habits

- the influence of the family (parents and siblings) on product and outlet selection and joint decision-making

- guidance or teaching by parents relating to shopping and consumer education

- $\quad$ shopping centres, shops (kinds, preferences, shopping experiences and children's proposals for improvements to shops and shopping malls)

- the value or influence of retailers on consumer education

An audiotape recorder was used to record the participants' feelings and ideas, and later transcribed for closer evaluation and analysis. The discussion list contained open-ended format questions. The moderator was also free to explore 
comments and issues raised by members of the group. Challenges faced during the sessions were to encourage the shy children to speak up and prevent the "know-it-all" from dominating the group. All of the children were given an equal chance to respond, thus ensuring even participation of the whole group. The moderator, who had the necessary knowledge and experience to deal with small children, helped the group to work together well, despite the level of immaturity and impatience of the children.

Described as "a conversation with a purpose" (Marshall \& Rossman, 1995: 80), the personal interviews with mothers were the second of the three methods employed in this study. The researcher conducted the interviews in an informal manner with the mothers in the comfort of their homes. The discussion list used in the interviews with children served as a framework for the interviews with the mothers. In order to make the assumptions in this study more objective, the interview data obtained from the children and the mothers were triangulated with the data gathered by means of a third method, namely the technique of picture drawing.

According to McNeal (1992: 216), obtaining information from children through drawings has been standard practice among psychologists for a century. It is now becoming standard practice among marketing researchers as well. Valuable insights can be gained through this technique because children sometimes have limited language abilities, or struggle to transmit what is on their minds. When children draw a picture, it reflects their non-verbal information on a particular topic that is stored in their minds. This could give marketing researchers reasons why a child likes and selects certain products, stores or shopping centres. Sometimes children have the tendency to become bored quickly, thus making the moderator's task of gathering information difficult. However, they respond eagerly and positively when asked to draw a picture. The 18 children who participated in the focus groups were asked to "draw what comes to your mind when you go shopping".

\section{FINDINGS}

Notes taken during the sessions by the moderator and the researcher, as well as the transcribed audio tapes, were studied, interpreted and systematically categorized in order to arrive at meaningful and valid research results. The pictures drawn by the children were also carefully scrutinized and discussed by the researcher and the moderator. The main findings that contribute to the achievement of the research objectives are summarized below. The findings 
presented correlate with the topics listed in the interview guide discussed previously.

- Introduction: All the children were exited about discussing the topic of shopping and family decision-making, because they love shopping and it is something they are involved in regularly. Remarks made by the mothers and the colourful drawings confirmed this finding. One mother, however, did not like shopping at all.

- General questions: Children tend to watch a lot of television. However, it was noted that they are beginning to replace TV watching with computer playing. A few mothers were concerned about the possible negative influence of computer games and children surfing the Net. Most children have their own money and a few even save some of it in a bank. They could not answer the question why they save money. It is assumed that they do so because their parents make suggestions in this regard. Parents allow their children to spend money on sweets, toys, and books or comics. Children understand the role of advertising. Two of the boys thought that most advertisements lie (probably because they heard this from their father or an older sibling).

- Family decision-making: In the majority of cases, mothers select the shopping centre, especially if they have more than one child to accommodate. Sometimes mothers with one child will allow the child to select a shopping centre, especially where the child has to buy something he or she needs for a school project. A degree of conflict occurs only when children insist on buying a specific item in a shop, normally as a result of peer pressure. The value of consumer socialization (education) in these cases was highlighted by the mothers who saw this as an opportunity to teach children consumer skills, for example looking at quality and price before buying. Girls exert a greater influence than boys when it comes to selecting clothes. An interesting fact was that not one of the respondents in the two samples considered or referred to the fact that older brothers or sisters play a significant role in the consumer socialization of younger children. Future research in this area may be of value to marketers.

Consumer education by parents: The children consider the role of the parents "to teach them important stuff about buying" in the same light as "telling us to brush our teeth before going to bed at night." The mothers who were interviewed, however, had different views on this matter. Some said that fathers should also be involved, others expect the school to do the job, while others again (the majority) felt that it is a joint effort of both parents and the school. This part of the discussion revealed clearly that different family types (husband-dominant, wife-dominant, joint/syncretic, individualized, or child-dominant), and even the size, age and family life cycle are factors that have an influence on the consumer socialization of children (Hawkins, Best \& Coney, 1998). The mothers agreed that they 
should teach their children not to spend money on "rubbish" and not to become "shopaholics".

- Shopping experiences: The analysis of the pictures drawn by the children revealed some interesting facts about their feelings and experiences as shoppers. The following points were clearly highlighted by the children in their drawings: they appear to be happy, enjoying themselves, have big smiles and are content with themselves. The mothers were depicted in most of the cases, and trolleys were present in almost all the drawings. The products most commonly shown were toys, books, sweets, and clothes. One girl's picture included a sign saying "sale". Children like to go shopping where they can see new things. During the personal interviews a few mothers mentioned that their children do not like to go shopping where it is hot or too crowded. When asked what extra features should be added to our shopping malls, the children suggested a gym, swimming pool, mini amusement parks and even learning centres. It should be noted that these suggestions were made mainly by children who had visited overseas shopping malls. One mother mentioned that she was prepared to pay for it if shopping malls had a nursery where children could be looked after.

- Role of retailers in consumer socialization: The participants in the two samples did not respond satisfactorily when questions were asked or discussions introduced by the interviewers about the role of retailers in the consumer education of children. None of the pictures drawn by the children depicted anything that showed children or their mothers interacting or communicating with store personnel. The reason for this is not clear, and is a possible topic for further investigation.

\section{DISCUSSION AND CONCLUSIONS}

The execution and results of this exploratory study confirm that it is a challenging task to research children. Marketers and researchers who wish to get "inside childrens' heads" should note that today's children are completely different from children, say, ten years ago. According to Liebeck (1998) children are now more knowledgeable - they have increased access to information and a greater knowledge and understanding of today's issues. They are truly the Intemet generation; and get their news and information primarily from television. Today's children also have disposable cash and visit multiple store formats every month. They understand the marketing and advertising campaigns presented to them. They are, however, rooted to home - their family is still their most important social group. 
The sample of only 10 mothers who participated in the personal interviews as well as the diverse answers and opinions given by them on certain topics, indicate that far more research needs to be done in this field. Unfortunately both the samples in this study included only white respondents. The transformation taking place in South Africa at present, stresses the need for a more multicultural research approach. Conducting research with children is possibly also hampered by the fact that some segments of society see children as vulnerable and in need of protection from marketing research. In this particular study, not all parents gave permission for their children to participate in the focus groups. Out of 26 pupils in one class, only 16 were allowed to participate.

McNeal (1993: 39) is of the opinion that a "... lifetime customer may be worth 100000 dollars to a retailer. It is well worth to understand and anticipate the needs and desires of even the smallest consumers." Little evidence could be found in this study to show that mothers and children consider the role of the retailer important in the socialization of children. This underlines the need for further research in this regard. McNeal (1999) reported that 68 per cent of a sample of retail chains attempt to target children as consumers with shopping facilitators, consumer education and promotion, and also train store personnel to serve children. Marketers and researchers are therefore compelled to use different methods to glean information about the feelings, attitudes and perceptions of children, relating to marketing activities. McGee (1997) mentions alternative ways to gather information from these special consumers, for example observational research, telephone and online focus groups and consumer panels.

\section{REFERENCES}

1 CARDWELL-GARDNER, T. \& BENNETT, J.A. (1999) "Television Advertising to Young Children: An Exploratory Study", Paper presented at the 1999 IMM Marketing Educators Conference, September: 22-4.

2 CARLSON, L. \& GROSSBART, S. (1994) "Family Communication Patterns and Marketplace Motivations, Attitudes, and Behaviours of Children and Mothers", Journal of Consumer Affairs, 28(1): 25-54.

3 ENGEL, J., BLACKWELL, R. \& MINIARD, P.W (1995) Consumer Behavior $\left(8^{\text {th }}\right.$ ed.) Harcourt Brace College Publishers, Florida.

4 HAWKINS, D.I., BEST, R. \& CONEY, K.A. (1998) Consumer Behaviour. Building Marketing Strategy ( $7^{\text {th }}$ ed.) McGraw-Hill, Boston.

5 JOHN, D.R. (1999) "Consumer Socialization of Children: A Retrospective Look at 25 Years of Research", Journal of Consumer Research, 26(3): 183-237. 
6 LEE, C.K. \& MARSHALL, R. (1998) "Measuring Influence in the Family Decisionmaking Process Using an Observational Method", Qualitative Market Research: An International Journal, 1(2): 88-98.

7 LIEBECK, L. (1998) "The Customer Connection: Children Under 13", Discount Store News, October: 55-7.

8 MARSHALL, C. \& ROSSMAN, G. (1995) Designing Qualitative Research ( $2^{\text {nd }}$ ed.) Sage Publications, London.

9 McGEE, T. (1997) "Getting inside Kids" Heads", American Demographics, 19(1): 53-7.

10 MCNEAL, J.U. (1973) An Introduction to Consumer Behaviour, Wiley, New York.

11 MCNEAL, J.U. (1992) Kids as Customers, Lexington Books, New York.

12 MCNEAL, J.U. (1993) "Born to Shop. (Children's Shopping Patterns)", American Demographics, 15(6): 34-9.

13 MCNEAL, J.U., HERNDO, N. \& YEH, C. (1993) "A Study of Children's Consumer Socialization over a Five-Year Period: Income, Spending and Saving", Asia Pacific Journal of Marketing and Logistics, 5(4): 48-62.

14 MCNEAL, J.U. \& YEH, C. (1993) "A Cross-Cultural Study of Children's Consumer Socialization in Hong Kong, New Zealand, Taiwan, and the United Nations", Asia Pacific Journal of Marketing and Logistics, 5(3): 56-69.

15 MCNEAL, J.U. \& Л, M. (1999) "Chinese Children as Consumers: An Analysis of Their Product Information Sources", Journal of Consumer Marketing, 16(4): 345-64.

16 MOSCHIS, G. (1987) Consumer Socialization: A Life Style Perspective, Lexington Books, MA.

17 NORTH, E.J. (1987) Multistapnavorsing oor Kinders in Reklame, Unpublished DCom Dissertation, University of South Africa.

18 NORTH, E.J. (1998) "Catch 'Em Young: Developing a Culture of Entrepreneurship Among Children", Paper presented at the 1998 SAESBA Conference, May 27-29.

19 STIPP, H. (1988) "Children as Consumers", American Demographics, 10(2): 26-33.

20 SHETH, J., MITTAL, B. \& NEWMAN, B. (1999) Customer Behavior: Consumer Behavior and Beyond. Dryden Press, New York.

21 Ward, S. (1974) "Consumer Socialization", Journal of Consumer Research 1(September): 1-14. 